\title{
A role for circadian clock in metabolic disease
}

\author{
Ippei Shimizu $^{1,2}$, Yohko Yoshida ${ }^{1,2}$ and Tohru Minamino ${ }^{1}$ \\ Many human behaviors and physiological activities show circadian rhythms. Circadian rhythms generated by central and \\ peripheral clocks maintain homeostasis, including the regulation of metabolic processes. Biological rhythmicity is important for \\ metabolic health, but circadian rhythms are affected and impaired by nocturnal activities and irregular food intake in modern \\ society. Disruption of sleep is an established risk factor for diabetes and is known to promote systemic metabolic dysfunction in \\ both humans and rodents. Metabolic stress promotes circadian clock disorders and modulation of clock gene expression has a \\ causal role in the development of metabolic dysfunction. Maintenance of a physiological circadian rhythm is crucial for \\ metabolic health and is an important strategy for combating obesity.
}

Hypertension Research (2016) 39, 483-491; doi:10.1038/hr.2016.12; published online 18 February 2016

Keywords: circadian clock; diabetes; metabolic stress

\section{INTRODUCTION}

In accordance with the daily rising and setting of the sun, most of our behaviors and physiological activities including metabolic processes show rhythmic coordination with a period of $\sim 24 \mathrm{~h}$. The master clock in the suprachiasmatic nucleus (SCN) coordinates oscillation in the peripheral organs, to maintain phase coherence within the whole body. Key clock components, such as Clock and Bmall, and clock-targeted molecules form a negative feedback loop that generates oscillation over a period of $\sim 24 \mathrm{~h}$. The number of obese people is increasing rapidly and this increase is the chief healthcare problem in many societies today. Studies have provided evidence that metabolic stress disturbs physiological clock oscillation, and that genetic manipulation of clock and clock-regulated genes causes the development of metabolic dysfunction. Data from these studies clearly suggest the existence of a negative feedback relation between circadian clock dysfunction and metabolic stress. Beginning with the characterization of mouse models with systemic genetic manipulation, recent studies have focused on the clocks (oscillators) in peripheral tissues such as the adipose tissue, liver and pancreas, and have examined the pivotal role of peripheral clocks in maintenance of tissue homeostasis and systemic metabolism. Physiological circadian oscillation is impaired in modern societies, owing to shift work, nocturnal social activities, jet lag and other factors. It has been well described that disorders of circadian rhythm promote systemic metabolic dysfunction associated with obesity or diabetes in both humans and rodents. In this review, we delineate the roles of the central and peripheral clocks in maintenance of metabolic homeostasis.

\section{MASTER CLOCK, PERIPHERAL CLOCKS AND THEIR REGULATORY COMPONENTS}

The master clock in the SCN is set at a periodicity of $\sim 24 \mathrm{~h}$ by retinal sensing of light and the most important timing cue (Zeitgeber) is transmission of light signals via the retinohypothalamic tract that facilitates adaptation to the geographical location. The master clock in the SCN transmits signals that coordinate oscillation in the peripheral organs and thereby ensures phase coherence within the body. Clock and Bmall are the most extensively studied molecules known to generate a circadian rhythm in the SCN and have been described as the 'master clock' or 'circadian pacemaker.' Clock and Bmall form a heterodimer complex, which binds to E-box motifs and upregulates the transcription of circadian genes, including those from the cryptochrome family (Cry1 and Cry2) and the period family (Per1, Per2 and Per3). Cry and Per proteins form a heterodimer that undergoes translocation to the nucleus and derepresses the Clock/ Bmall complex through proteolytic degradation, thereby creating a negative feedback loop with an $\sim 24 \mathrm{~h}$ circadian rhythm (primary feedback loop). Rev-erb $\alpha$ and Rev-erb $\beta$ are positively regulated by Clock/Bmall at the transcriptional level and these Rev-erbs in turn inhibit Bmall and Clock gene expression to form another negative feedback loop (secondary feedback loop). In addition to this central clock, almost all cells in the body express molecules controlled by the autonomous cell clock. In all tissues, at least $20 \%$ of transcripts are under circadian control and the feeding/fasting cycle is the critical regulator (Zeitgeber) of this 'peripheral clock'. Rhythmic feeding is essential for the circadian expression of genes in the liver and, interestingly, restriction of feeding in the rest phase (light period) can disrupt coordination of the central SCN clock with the peripheral

\footnotetext{
${ }^{1}$ Department of Cardiovascular Biology and Medicine, Niigata University Graduate School of Medical and Dental Sciences, Niigata, Japan and ${ }^{2}$ Division of Molecular Aging and Cell Biology, Niigata University Graduate School of Medical and Dental Sciences, Niigata, Japan

Correspondence: Professor T Minamino, Department of Cardiovascular Biology and Medicine, Niigata University Graduate School of Medical and Dental Sciences, 1-757 Asahimachidori, Chuo-ku, Niigata 951-8510, Japan.

E-mail: t_minamino@yahoo.co.jp

Received 6 January 2016; revised 17 January 2016; accepted 18 January 2016; published online 18 February 2016
} 
clocks. ${ }^{1}$ Under normal conditions, the peripheral clocks are directly synchronized by the SCN via hormones and indirectly through behavior. In rodents stressed by conflicting feeding cycles, the SCN uses more direct signals to counteract dominant signals that depend on metabolic cycles. Various aspects of systemic metabolism, such as glucose homeostasis, are under the control of both the central and peripheral clocks. Diverse metabolic pathways involved in carbohydrate, lipid and amino acid metabolism are regulated by the circadian clock, both directly (through transcriptional regulation of metabolic enzymes by Clock-Bmall heterodimer) and indirectly (via clock-regulated release of endocrine factors), as covered in the elegant review by Young et al. ${ }^{2}$ There is accumulating evidence that dysregulation of clock genes has a causal role in metabolic disorders, based on findings initially obtained in systemic knockout (KO) mouse models.

\section{Clock}

The mutant Clock transgene $\left(\right.$ Clock $\left.^{\Delta 19}\right)$ has deletion of exon 19, resulting in loss of 51 amino acids in the C-terminal of the Clock protein. ${ }^{3}$ Mutant Clock $^{\Delta 19}$ protein can form heterodimers with Bmal1 but is unable to initiate target gene transcription. Turek et al. ${ }^{4}$ described the pronounced metabolic phenotype associated with Clock mutation. Clock mutant mice with a C57BL/6J background show disturbance of circadian rhythmicity and develop obesity and metabolic syndrome along with hyperphagia, hyperlipidemia (elevation of triglycerides and cholesterol), hyperglycemia, hyperleptinemia and hypoinsulinemia. ${ }^{4}$ Pancreatic islets are significantly reduced in Clock mutant mice with a C57BL/6J background and these animals show marked impairment of glucose-induced insulin secretion. ${ }^{5}$ Shostak et al. ${ }^{6}$ reported that cholesterol is elevated in Clock mutant mice, but they did not demonstrate circadian variation in either genotype. In their study, serum triglyceride levels showed rhythmic variation that was indistinguishable between genotypes. Serum-free fatty acid and glycerol levels showed a robust circadian profile in wild-type (WT) mice, but this rhythmicity was reduced or abolished in Clock mutant mice, suggesting that fatty acid release from triglyceride stores is regulated by a clock-dependent mechanism. Consistent with this concept, epididymal fat weight and adipocyte size were greater in the Clock mutant mice. ${ }^{6}$ Taken together, the results of these studies indicate that Clock has a crucial role in the maintenance of metabolic health.

\section{Bmal1}

Although Clock and Bmall form a heterodimer to exert their biological effects, the metabolic profile of mice with Bmal1 depletion is not a phenocopy of that seen in Clock mutant mice. It was reported that 8-week-old male, Bmall-null mice with a mixed background (C57BL/6 and 129/SV) become slightly lean when fed a normal chow diet and show nonsignificant reduction of body weight when maintained on a high-fat diet. In contrast, reduction of body weight was not significant in 8-week-old female mice with a mixed background fed a normal chow diet, while there was slight but significant weight gain when maintained on a high-fat diet. Epigonadal and retroperitoneal fat pad weight were remarkably increased in male and female mice when maintained on both diets. ${ }^{7}$ In another study, Bmall KO mice with a C57BL/6J background showed a similar body weight to their littermates until 12 weeks of age for males and 22 weeks for females, after which significant reduction occurred steadily. This agerelated decline of body weight was thought to be due to the premature aging phenotype of Bmall $\mathrm{KO}$ mice. ${ }^{8}$ The gonadal fat to body weight ratio was similar in Bmal1 $\mathrm{KO}$ and WT mice until 20 weeks of age, although the KO group showed remarkable reduction of body weight after 12 weeks (males). Interestingly, the total fat volume measured with an EchoMRI whole body composition analyzer was significantly higher in the $\mathrm{KO}$ group from 4 to 20 weeks of age and then showed nonsignificant reduction at 40 weeks of age. ${ }^{8}$ Glucose levels were reported to be similar in both genotypes, whereas plasma levels of triglycerides, fatty acids and leptin were increased in Bmall-null mice (mixed background) at 8 weeks of age. ${ }^{7}$ It has also been demonstrated that Bmal1-null mice with a C57BL/6J background develop pancreatic $\beta$-cell dysfunction associated with impaired insulin secretion, possibly due to a low mitochondrial membrane potential and reduced generation of ATP. ${ }^{5,9}$ Mitochondria isolated from the livers of Bmal1-null mice show reduced oxygen consumption when provided with fatty acids as a substrate, but oxygen consumption is not reduced in the presence of substrates that supply electrons directly to mitochondrial complex I or II. These results suggest that reduced $\beta$-oxidation is responsible for impaired mitochondrial respiration in the livers of Bmal1-null mice. ${ }^{10}$

\section{Per}

Per2-null mice with a 129/sv background have a normal food intake and show no changes of locomotor activity or SCN rhythm but lose weight from 6 weeks of age. The weight loss becomes significant from 10 weeks of age (the KO group are significantly heavier at 3-5 weeks of age) and is associated with significant reduction of adipose tissue mass and plasma lipid levels along with a high oxygen consumption ratio. ${ }^{11}$ Another study showed that Per2-null mice with a C57BL/6J background become obese when fed either a normal chow or a high-fat diet throughout the observation period (4-16 weeks of age). In addition, the fat mass/ body weight ratio was increased in Per2-null mice receiving a high-fat diet, along with high plasma insulin levels, increased glucose-stimulated insulin secretion and delayed insulin clearance. ${ }^{12,13}$ In agreement with Yang et al., ${ }^{12}$ Kettner et al. ${ }^{8}$ reported that both male and female Per1 ${ }^{-1-}$ Per2 ${ }^{-1-}$ double KO mice with a C57BL/6J background showed weight gain relative to WT controls until 35-40 weeks of age under a normal light/dark cycle. They found that $\mathrm{Per}^{-1-} \mathrm{Per}^{-1-}$ double KO mice had a higher gonadal fat/body weight ratio at 7 and 20 weeks of age, whereas the total fat/body weight ratio was significantly higher from 3-4 to 20 weeks of age and still showed a nonsignificant increase at 40 weeks. Interestingly, although body weight was significantly reduced by chronic jet lag compared with WT mice, gonadal fat pad and total fat composition were similar between $\mathrm{KO}$ and WT mice from 3 to 20 weeks of age, possibly because $\mathrm{KO}$ mice compensate for insufficient energy storage in the adipose tissue by increasing fat accumulation. ${ }^{8}$

\section{Cry}

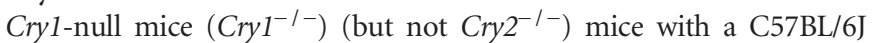
background show resistance to high-fat-induced obesity. ${ }^{14}$ It was also

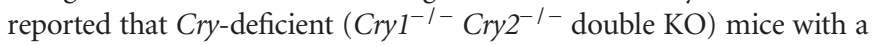
C57BL/6 background exhibit elevation of blood glucose in response to acute feeding after an overnight fast and show reduced glucose clearance in the glucose tolerance test but have a normal response to insulin. ${ }^{15}$ Furthermore, both male and female $\mathrm{Cr} y 1^{-1-} \mathrm{Cry} 2^{-1-}$ double $\mathrm{KO}$ mice with a $\mathrm{C} 57 \mathrm{BL} / 6 \mathrm{~J}$ background exhibit dramatic reduction of body weight up to 35-40 weeks of age before developing other abnormalities such as cancer. ${ }^{8}$ Although $\mathrm{Cr} y 1^{-1-} \mathrm{Cr} y 2^{-1-}$ double $\mathrm{KO}$ mice had a significantly lower gonadal fat/body weight ratio at 7 and 20 weeks of age, the total fat/body weight ratio was similar to that of WT mice from 3 to 20 weeks of age and then showed significant reduction at 40 weeks. 


\section{Rev-erbo}

Expression of the nuclear receptor Rev-erb $\alpha$ is regulated by the Clock/Bmall heterodimer complex. Rev-erb $\alpha$ protein binds to the retinoid-related orphan receptor response element within the Bmall promoter and suppresses transcription of Bmall. Rev-erba directly regulates the expression of multiple enzymes involved in hepatic gluconeogenesis, such as glucose-6-phosphatase and phosphoenolpyruvate carboxykinase, making it a critical regulator of both clock function and metabolism. Rev-erb $\alpha$-depleted mice with a C57BL/6J background show mild hyperglycemia and an increase of the plasma insulin level, but it is interesting that systemic insulin resistance does not develop. Rev-erb $\alpha \mathrm{KO}$ mice use fatty acids in preference to glucose and the plasma fatty acid level is significantly reduced by fasting. Body weight is similar between the genotypes maintained on a normal chow diet but Rev-erb $\alpha$-depleted mice are more susceptible to dietary obesity and weight gain, as well as an increase of perigonadal and retroperitoneal white adipose tissue weight in response to metabolic stress. ${ }^{16}$ Rev-erb $\alpha$-null mice are also known to develop mild hepatic steatosis. ${ }^{17}$ Mice with systemic depletion of Rev-erb $\alpha$ and Rev-erb $\beta$ on a C57BL/6 background (CAG-CreER Rev-erbof ${ }^{f l f l} \operatorname{Rev}$-erb $\beta^{f l / f l}$ ) show reduced physical activity associated with hyperglycemia and high circulating triglyceride levels. ${ }^{18}$ Conversely, it was reported that a rev-erb agonist suppresses weight gain by reducing fat mass and improves both dyslipidemia and hyperglycemia. ${ }^{19}$ A recent study demonstrated that Rev-erb $\alpha$ is highly expressed in oxidative skeletal muscle. Lkb1-Ampk-Sirt1-Ppargcl $\alpha$ signaling is deactivated in $N r 1 d 1^{-1-}$ (the gene coding for Rev-Erb $\alpha$ ) mice, which results in the reduction of mitochondria and oxidative function in skeletal muscle, leading to reduced exercise capacity. ${ }^{20}$ Considering that low exercise capacity is linked to obesity, reduced Rev-erb $\alpha$ signaling may also promote obesity in an indirect manner. Recently, Rev-erb $\alpha$ was shown to have discrete roles when coupling metabolism to the clock. In all tissues, Rev-erb $\alpha$ binds directly to the genome at cognate sites and competes with activating retinoid-related orphan receptor transcriptional factor to exert its clock regulatory function. In contrast, Rev-erb $\alpha$ primarily regulates metabolic genes by recruiting the histone deacetylase-3 co-repressor to sites where it is tethered by cell-specific transcription factors. ${ }^{21}$

As described above, various studies based on systemic genetic depletion of clock-related genes have indicated that these molecules are involved in the regulation of systemic metabolic homeostasis. The roles of the central and peripheral clocks and clock-regulated molecules in maintenance of metabolic health are discussed in the next section.

\section{CENTRAL CLOCK}

The circadian rhythm is generated in the SCN of the anterior hypothalamus. Rhythmic information is transferred from the SCN to the central nervous system and to peripheral organs, and this coordinates physiological and behavioral functions by synchronizing metabolic and endocrine factors. Dietary obesity does not affect the expression or rhythmicity of Bmal1, Clock and Per2 in the hypothalamus, but orexigenic (Agrp and Npy) and anorexigenic (Pomc and Cart) neuropeptides show altered diurnal expression patterns in male C57BL/6J mice, and these changes are associated with attenuated diurnal rhythms of feeding and locomotor activity. ${ }^{22}$ Several lines of evidence have indicated that SCN malfunction disturbs systemic energy homeostasis. Rats with SCN lesions do not have rhythmic food intake and the daily rhythms of plasma glucose and insulin are also abolished..$^{23,24}$ It was recently reported that $\mathrm{C} 57 \mathrm{BL} / 6 \mathrm{~J}$ mice with bilateral microlesions of the SCN show disturbance of energy balance, increased body weight and fat weight (no increase of lean weight), and development of systemic insulin resistance. ${ }^{25}$ The mechanisms by which metabolic stress promote SCN dysfunction remain to be defined. It has been shown that a high-fat diet reduces induction of the immediate early gene $c$-fos in the SCN by light and leptin plays an important role in this response. ${ }^{26}$ In addition, disturbance of the adipocyte clock results in altered feeding rhythms and disruption of the normal daily rhythm of circulating polyunsaturated fatty acids. ${ }^{27}$ Although these reports indicate that a bidirectional relationship exists between the peripheral clocks and the SCN, further studies are needed to determine how metabolic stress promotes central clock dysfunction both directly and indirectly.

\section{PERIPHERAL CLOCKS}

The major roles of the peripheral clocks are orchestration of food intake and metabolic processes. It is well known that the levels of a large number of metabolites show oscillation in the tissues and plasma, and there is accumulating evidence that perturbation of peripheral clock expression has a causal role in the development of systemic metabolic dysfunction.

\section{Adipose tissue}

White adipose tissue was initially thought to be mainly involved in energy storage, but it is now widely accepted that it also has an endocrine function and secretes a variety of factors referred to as adipokines. Metabolic stress associated with obesity leads to the development of sterile inflammation in white adipose tissue, which promotes a shift toward production of pro-inflammatory adipokines that contributes to the development of systemic metabolic dysfunction and diabetes. There is evidence that peripheral clocks have a crucial role in the maintenance of adipose tissue homeostasis. In the epididymal fat, inguinal fat and brown adipose tissue of C57BL/6J mice, clock genes (Bmal1, Per1, Per2, Per3, Cry1 and Cry2) and clockcontrolled downstream genes (Rev-erb $\alpha$ and $R e v-e r b \beta$ ) show 24-h rhythms. ${ }^{28}$ In addition, expression of several clock genes such as Per2, Cry1 and Bmal1 in the adipose tissue is associated with features of metabolic syndrome. ${ }^{29}$ Furthermore, the rhythmic expression of clock genes or adipokines in perigonadal adipose tissue is slightly attenuated in obese KK mice and significantly suppressed in diabetic KK-Ay mice, ${ }^{30}$ while dietary obesity reduces expression of Bmal1 and Per2 in the visceral adipose tissue of C57BL/6J mice. Moreover, modulation of clock genes per se has been shown to have a causal role in the development of systemic metabolic dysfunction. Adipocyte-specific Bmall KO (aP2-Cre Bmal1 ${ }^{f l / f l}$ ) mice with a C57BL/6J background show increased food intake and develop obesity when fed a chow diet. ${ }^{27}$ Disruption of adipocyte clock function results in temporal changes in plasma concentration of polyunsaturated fatty acids, leading to corresponding changes in the expression of neurotransmitters responsible for appetite regulation in hypothalamic feeding centers. The magnitude of the effect on hypothalamic expression of neurotransmitters is sufficient to induce changes in feeding activity, leading to disruption of the normal feeding rhythm. These changes occur without alteration in the rhythmic expression of circadian clock genes (including Bmal1) in the hypothalamus, suggesting a direct effect of the adipocyte circadian clock on hypothalamic feeding centers without the participation of the local circadian clocks.

The role of clock genes may vary among different types of adipose tissue. Examination of subcutaneous fat from obese humans shows no abnormalities in the rhythmic transcription of clock genes and subcutaneous fat from rodents shows only mild impairment compared with visceral fat. These findings indicate that the expression profile of 
clock genes varies between different types of fat. ${ }^{31,32}$ Brown adipose tissue was initially considered to be an organ mainly involved in thermogenic responses, but subsequent evidence has suggested that it is a critical regulator of systemic metabolism. ${ }^{33,34} \mathrm{Nam}$ et al. ${ }^{35}$ demonstrated that suppression of Bmall promotes the differentiation of brown adipocytes. Whitening of interscapular brown adipose tissue by dietary obesity was significantly suppressed in aP2-Cre Bmal flfl mice, and although these mice gained weight compared with their littermate controls, they lost significantly more weight than their littermate controls during the 24 -h cold tolerance test. ${ }^{35}$ It was also reported that depletion of Bmall from the adipose tissue led to a significant increase of adipocyte size in epididymal fat, but did not induce adipose tissue inflammation. ${ }^{27}$

In recent times, expression of leptin in the adipose tissue was shown to be regulated by Bmal1/Clock-modulated binding of C/EBP $\alpha$ to the leptin promoter, leading to rhythmic transcription of this molecule in the adipose tissue and an oscillatory pattern of blood levels, and this pattern was found to be independent of food intake. ${ }^{8}$ Leptin is a strong inhibitor of appetite acting on the hypothalamus and leptin resistance develops in persons with obesity. Kettner et al. ${ }^{8}$ reported that leptin signaling in pro-opiomelanocortin neurons is subject to circadian control, and that circadian dysfunction induced by chronic jet lag promotes leptin resistance. However, further studies are needed to determine how circadian dysfunction promotes leptin resistance.

Development of sterile chronic inflammation in white adipose tissue is well known to have a pathological role in the progression of systemic metabolic dysfunction. Clock genes are central to regulating the responses of immune cells. Myeloid cell-specific disruption of Per1 and Per2 has been reported to increase body weight and visceral adipose tissue weight, as well as exacerbating dietary adipose tissue inflammation and insulin resistance. ${ }^{36}$ In addition, Rev-erb $\alpha$ was shown to repress $\mathrm{Ccl} 2$ expression through a Rev-erbo-binding motif in the $\mathrm{Ccl} 2$ promotor region and to inhibit CCL-2 signaling pathways. ${ }^{37}$ These results suggest a central role of clock genes in the maintenance of adipose tissue homeostasis.

\section{Liver}

The liver has a major role in the maintenance of systemic metabolism, as it is involved in glycogen storage, protein synthesis, hormone production and detoxification. Metabolic stress is involved in the development of nonalcoholic fatty liver disease and this promotes pathologic changes related to cardiometabolic disorders. ${ }^{38}$ Clock genes are also known to be involved in regulation of liver homeostasis. The hepatic expression of Per1 and Cry2 (but not Per2, Bmal1 or Cry1) was reported to be different in KK-Ay mice. ${ }^{30}$ In addition, liver-specific depletion of Bmal1 in mice with a mixed C57BL/6x129 background was reported to enhance glucose clearance in association with fasting hypoglycemia, while these animals maintained normal insulin production and a normal body fat content, suggesting that hepatic Bmall governs the cyclic expression of biochemical pathways that offset systemic fluctuations due to carbohydrate ingestion at regular mealtimes. ${ }^{39}$ Retinol-binding protein-4 was reported to be correlated with insulin resistance and it was recently shown to oscillate under the control of Bmall and to act as a hepatokine. Liver-specific depletion of Bmall resulted in the reduced oscillation of retinol-binding protein-4 expression and increased systemic insulin sensitivity, while overexpression of retinol-binding protein- 4 in the liver reversed the insulin-sensitizing effect of liver-specific Bmall depletion. ${ }^{40}$ Moreover, liver-specific Bmal1 depletion caused elevation of the plasma low-density lipoprotein(LDL)/very low-density lipoprotein(VLDL) cholesterol level due to disruption of the proprotein convertase subtilisin/ kexin type 9/LDL receptor regulatory axis. ${ }^{41}$ Another study showed that depletion of Cry1 and Cry2 in the liver increased hepatic levels of mRNAs for gluconeogenesis genes (G6pc and Pck1) and resulted in elevation of the circulating glucose concentration in $d b / d b$ mice, whereas hepatic overexpression of Cryl lowered fasting blood glucose and improved whole body insulin sensitivity. ${ }^{42}$ These results suggest that suppression of liver clock genes is able to suppress the genes involved in gluconeogenesis and reduce hepatic glucose production in association with improvement of glucose tolerance. Finally, Rev-erb $\alpha$-null mice develop mild hepatic steatosis, but depletion of Rev-erb $\beta$ from the liver in these mice by using adenovirus to deliver short hairpin RNA for Rev-erb $\beta$ leads to severe hepatic steatosis. ${ }^{17}$

\section{Pancreas}

Patients with type 2 diabetes develop pancreatic $\beta$-cell dysfunction and reduced insulin secretion, which sometimes precede the diagnosis of diabetes. Islet cells have an autonomous circadian rhythm and insulin is released from the pancreatic islets in a circadian manner. ${ }^{43}$ Islet expression of Clock, Bmal1, Per1, Per2 and Rev-erb $\alpha$ shows daily oscillation in mice and rats. ${ }^{44,45}$ In addition, islet expression of PER2, PER3 and CRY2 is reduced in patients with diabetes ${ }^{46}$ and a high-fat diet is reported to increase islet levels of Clock and Per1 mRNA in mice. ${ }^{44}$ Furthermore, disruption of circadian rhythms and dietary obesity act synergistically to promote $\beta$-cell failure and diabetes in male rats. ${ }^{47}$ Moreover, pancreatic islet-specific depletion of Bmal1 $\left(P d x C r e B_{\text {Ball }}^{f l f f l}\right)$ in mice with a C57BL/6J background leads to hyperglycemia and glucose intolerance associated with a low insulin level. The pancreatic insulin content is similar in littermate controls and $\mathrm{KO}$ mice, suggesting that insulin secretion is impaired in these mice. ${ }^{5}$ In the pancreas, Clock/Bmall are co-localized with pancreatic transcriptional factor $\mathrm{Pdx} 1$ within different active enhancers from those controlling rhythmic metabolic gene networks in the liver, suggesting that cell-specific enhancers underlie the circadian regulation of peripheral metabolism. ${ }^{48}$ An in vitro study showed that downregulation of Rev-erb $\alpha$ in islet cells by small interfering RNA led to the reduction of glucose-induced insulin secretion. ${ }^{44}$ In addition, $\beta$-cell-specific depletion of Bmal1 was reported to increase oxidative stress in mice, ${ }^{49}$ while Marcheva et al. ${ }^{5}$ suggested that the $\beta$-cell circadian clock has a crucial role in the regulation of key transcription factors involved in $\beta$-cell growth, proliferation and maturation. These findings suggest that clock genes have a critical role in maintenance of both pancreatic and systemic metabolic homeostasis.

\section{Blood vessels}

Although dietary obesity has a marked effect on clock genes in the visceral fat, liver and pancreas, clock gene cycling is well preserved in the aorta. ${ }^{32}$ This indicates that blood vessels may be more resistant to disruption of clock function than some other organs/tissues, and that longer exposure to stress may be required to affect the vessels, but there is also evidence that clock genes are crucial for maintaining vascular homeostasis. Both thrombomodulin and plasminogen activator inhibitor-1, which are predominantly expressed by vascular endothelial cells, are known to be regulated by clock genes. ${ }^{50,51}$ In addition, aortic endothelial dysfunction has been reported in Clock mutant mice or mice with systemic Bmal1 depletion. ${ }^{52}$ Per2 mutant mice also develop endothelial dysfunction due to reduced release of nitric oxide from endothelial cells associated with low expression of vasodilatory prostaglandins. ${ }^{53}$ Furthermore, suppression of nitric oxide synthase activity causes the impairment of clock gene expression. ${ }^{54}$ Endothelial cell depletion of Bmall (in Cre ${ }^{\text {Tek }}$ Bmall ${ }^{\text {fl/fl }}$ 

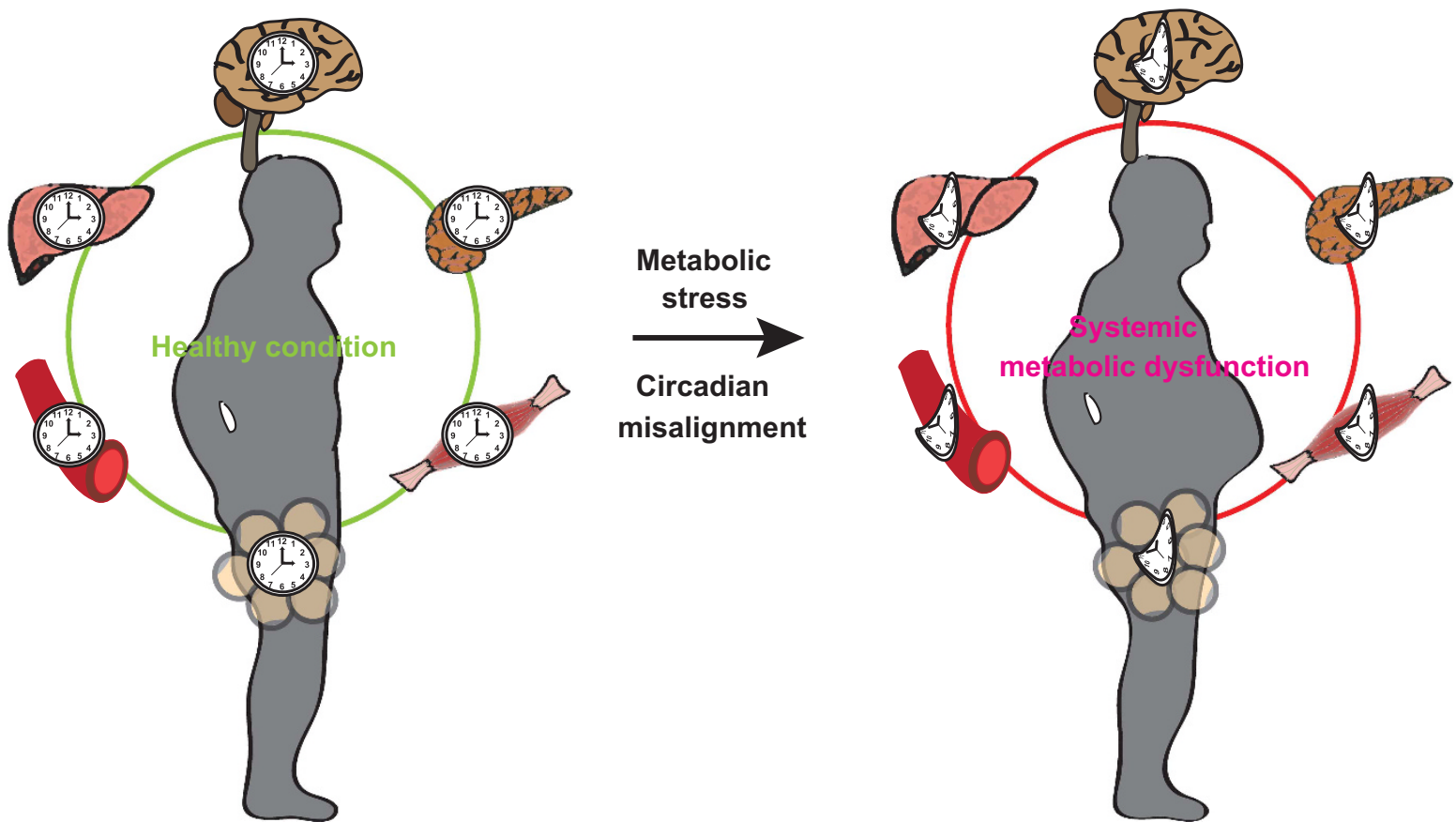

Figure 1 In the normal state, circadian rhythms generated by the central and peripheral clocks coordinate metabolic processes to maintain health. Metabolic stress or circadian misalignment due to nocturnal activities or jet lag leads to clock dysfunction that promotes systemic metabolic dysfunction. Studies performed in murine transgenic models have indicated that peripheral clocks, especially those in adipose tissue and the pancreas, are crucially involved in the maintenance of metabolic homeostasis, suggesting the existence of a negative feedback loop between metabolic stress and clock dysfunction.

mice with a C57BL/6J background) disrupts the oscillatory expression of endothelial genes (such as Claudin-5, Tie-1 and Tek) and alters the function of core clock component Per2, suggesting that clock genes are involved in regulating vascular endothelial function. Interestingly, $\mathrm{Cre}^{\mathrm{Tek}}$ Bmall $^{\mathrm{fl} / \mathrm{fl}}$ mice show reduced locomotor activity along with elevation of the heart rate and low blood pressure. ${ }^{55}$ The metabolic phenotypes were not extensively described in these studies; hence, it is still unclear whether modulation of vascular clock genes leads to systemic metabolic dysfunction. Considering the pathological role of endothelial cell dysfunction and/or capillary rarefaction affecting key metabolic organs in the development of systemic metabolic disorders, it is highly possible that disruption of the circadian clock in vascular endothelial cells promotes systemic metabolic dysfunction. ${ }^{33,56}$

\section{Skeletal muscle}

Skeletal muscle is considered likely to become a therapeutic target in the fight against obesity. ${ }^{57}$ Izumiya et al. ${ }^{58}$ have shown that promoting hypertrophy of skeletal muscle fibers decreases body weight due to reduction of visceral fat mass and atrophy of white adipocytes. Dietary obesity does not affect rhythmic oscillation of clock gene transcription in skeletal muscle. ${ }^{32}$ Skeletal muscle-specific KO models have not been extensively analyzed and there is limited evidence about the role of skeletal muscle clock genes in the maintenance of systemic metabolic homeostasis. Muscle-specific inactivation of Bmal1 in mice (Mlclf-Cre Bmal1 $^{f l / f l}$ with a C57BL/6 background) was reported to lead to weight gain after $\sim 30$ weeks of age compared with WT littermates, although epididymal fat pad weight did not differ between the genotypes at 5 months of age. These mice did not develop systemic glucose metabolic dysfunction, but showed reduction of Glut4 expression in skeletal muscle associated with impairment of insulin-induced glucose uptake by muscle. ${ }^{59}$ Mice with inducible muscle-specific Bmal1 $\mathrm{KO}$ (iMS-Bmal1 ${ }^{-/-}$) were generated on a mixed background $(\mathrm{C} 57 \mathrm{BL} / 6 \mathrm{xC} 3 \mathrm{H})$ by crossing human skeletal actin-MerCreMer mice with Bmalf flffl mice. These mice developed muscle weakness and showed an increase of glycolytic type II fibers associated with muscle fibrosis, but there were no changes of feeding, physical activity or glucose tolerance. ${ }^{59,60}$

\section{Microbiota}

The microbial gut flora influence a broad range of physiological processes including metabolism and are important as a regulator of obesity and systemic metabolic disorders. ${ }^{61}$ In both mice and humans, the intestinal flora exhibit diurnal oscillation that is influenced by feeding rhythms. Ablation of the host molecular clock by whole-body depletion of Per1/Per2 or induction of jet lag impairs feeding rhythmicity and leads to aberrant diurnal fluctuation of the gut flora with dysbiosis, contributing to the development of glucose intolerance and obesity. ${ }^{62}$ In addition, Bmal1-null mice show loss of rhythmic variation in the composition of the fecal flora and changes of bacterial abundance in feces. ${ }^{63}$ The role of the microbial circadian clock in the regulation of homeostasis in metabolically active organs, such as the skeletal muscle, liver and fat tissue, is yet to be defined.

\section{METABOLIC STRESS PROMOTES CLOCK GENE DYSFUNCTION}

In the liver and adipose tissue, many nuclear receptors display rhythmic patterns of expression and at least $20 \%$ of transcripts in all tissues are thought to be under circadian control. Perturbation of metabolic pathways in mice with dietary obesity is associated with alterations in the amplitude of circadian oscillation and lengthening of the period, and peripheral clocks show phase shift in a mouse model of type 2 diabetes. ${ }^{64}$ Dietary obesity alters the circadian rhythm of various behaviors. Mice normally eat during the night, but mice fed a high-fat diet start to consume a higher percentage of their daily food intake during the light phase along with attenuated expression of clock and metabolic genes in the liver and adipose tissue. ${ }^{22}$ It has been reported that circadian output genes show dramatic changes in obese 
Table 1 Phenotypes of clock gene mutant mice

\begin{tabular}{|c|c|c|c|c|c|c|c|c|c|c|}
\hline References & Organ & Gene & $\begin{array}{l}\text { Tg mice } \\
\text { analyzed }\end{array}$ & $B W$ & Hyperphagia & $\begin{array}{l}\text { Physical } \\
\text { activity }\end{array}$ & Hyperglycemia & Hyperlipidemia & Hypoinsulinemia & Background \\
\hline Rudic et al. ${ }^{86}$ & Systemic & Clock & Clock $^{\Delta 19}$ & Similar & ND & ND & ND & ND & ND & ND \\
\hline Turek et al. ${ }^{4}$ & Systemic & Clock & Clock $^{\Delta 19}$ & Increase & Yes & Reduced & Yes & Yes & Yes & C57BL/6J \\
\hline Oishi et al. ${ }^{50}$ & Systemic & Clock & Clock $^{\Delta 19}$ & Similar ${ }^{a}$ & Yes & ND & No & No & $\mathrm{No}^{\mathrm{b}}$ & $\begin{array}{l}\text { Mixed (C57BL } \\
\text { 6JxBALB/cxICR) }\end{array}$ \\
\hline Marcheva et al. ${ }^{5}$ & Systemic & Clock & Clock $^{\Delta 19}$ & ND & ND & ND & Yes & ND & Yes & C57BL6J \\
\hline Doi et al.88 & Systemic & Clock & Clock $k^{\Delta 19}$ & ND & ND & ND & No & ND & No & ICR \\
\hline Shostak et al. ${ }^{6}$ & Systemic & Clock & Clock $^{\Delta 19}$ & Increase & Yes & Normal & ND & No & ND & C57BL/6J \\
\hline Rudic et al. ${ }^{86}$ & Systemic & Bmal1 & Bmal1 KO & ND & ND & ND & No & Yes & ND & ND \\
\hline Lamia et al. ${ }^{39}$ & Systemic & Bmal1 & Bmal1 KO & Increase & ND & Normal & Yes & ND & Yes & $\begin{array}{l}\text { Mixed (C57BL } \\
6 \times 129)\end{array}$ \\
\hline Kennaway et al. ${ }^{7}$ & Systemic & Bmal1 & Bmal1 KO & Similar-Leanc & ND & ND & No & Yes & Yes & $\begin{array}{l}\text { Mixed (C57BL } \\
6 \mathrm{Jx} 129 / \mathrm{SV})\end{array}$ \\
\hline Kettner et al. ${ }^{8}$ & Systemic & Bmal1 & Bmal1 KO & Similar-lean ${ }^{d}$ & ND & ND & ND & ND & ND & C57BL/6J \\
\hline Nam et al. ${ }^{35}$ & Systemic & Bmal1 & Bmal1 KO & Increase & ND & ND & ND & ND & ND & C57BL/6 \\
\hline Grimaldi et al. ${ }^{11}$ & Systemic & Per2 & Per2 KO & Lean ${ }^{\mathrm{e}}$ & No & Normal & ND & $\mathrm{No}^{f}$ & ND & $129 / \mathrm{sv}$ \\
\hline Yang et al. ${ }^{12}$ & Systemic & Per2 & Per2 KO & Increase & Nog & ND & ND & ND & ND & C57BL/6J \\
\hline Zhao et al. ${ }^{13}$ & Systemic & Per2 & Per2 KO & ND & ND & ND & $\mathrm{No}^{h}$ & ND & $\mathrm{No}^{\mathrm{h}}$ & C57BL6J \\
\hline Chappuis et al. ${ }^{89}$ & Systemic & Per2 & Per2 KO & Similar & No & ND & ND & No & ND & $\begin{array}{l}\text { Mixed (129S5/ } \\
\left.\text { C57BL/6-Tyr }{ }^{-B r d}\right)\end{array}$ \\
\hline Zani et al. ${ }^{90}$ & Systemic & Per2 & Per2 KO & Similar & No & ND & $\mathrm{No}^{\mathrm{i}}$ & ND. & Yes & $\begin{array}{l}\text { Mixed (129S5/ } \\
\left.\text { C57BL/6-Tyr }{ }^{-B r d}\right)\end{array}$ \\
\hline Lamia et al. ${ }^{39}$ & Systemic & Per1/Per2 & Per1/Per2 DKO & Lean & ND & ND & Yes & ND & ND & 129S1/SvImJ \\
\hline Kettner et $a l^{8}$ & Systemic & Per1/Per2 & Per1/Per2 DKO & Increase & No & Normal & ND & ND & ND & C57BL/6J \\
\hline Lamia et al. ${ }^{15}$ & Systemic & Cry 1 & Cryl KO & ND & ND & Normal & Yes & ND & ND & C57BL/6 \\
\hline Griebel et al. ${ }^{14}$ & Systemic & Cryl & Cryl KO & Similar ${ }^{j}$ & No & ND & No & No & ND & C57BL6J \\
\hline Lamia et al. ${ }^{15}$ & Systemic & Cry2 & Cry2 KO & ND & ND & Normal & Yes & ND & ND & C57BL/6 \\
\hline Lamia et al. ${ }^{15}$ & Systemic & Cry $1 /$ Cry 2 & Cry $1 /$ Cry2 DKO & ND. & ND & Normal & Yes & ND & ND & C57BL/6 \\
\hline Barclay et al. ${ }^{90}$ & Systemic & Cry $1 /$ Cry2 & Cry1/Cry2 DKO & Lean $^{k}$ & $\mathrm{No}^{\mathrm{k}}$ & Reduced' & Yes $^{m}$ & No & $\mathrm{No}^{\mathrm{m}}$ & C57BL6J \\
\hline Kettner et al. ${ }^{8}$ & Systemic & Cry $1 /$ Cry 2 & Cry1/Cry2 DKO & Lean & No & Reduced & ND & ND & ND & C57BL/6J \\
\hline Delezie et al. ${ }^{12}$ & Systemic & $R e v-e r b \alpha$ & Rev-erb $\alpha \mathrm{KO}$ & Similar ${ }^{\mathrm{n}}$ & No & Normal & Yes & No & No & C57BL/6J \\
\hline Woldt et al..$^{20}$ & Systemic & $R e v-e r b \alpha$ & Rev-erb $\alpha \mathrm{KO}$ & ND & ND & Reduced & ND & ND & ND & SV129/OlaHsd \\
\hline Cho et al. ${ }^{18}$ & Systemic & $\begin{array}{l}\text { Rev-erb } \alpha / \\
\text { Rev-erb } \beta\end{array}$ & $\begin{array}{l}\text { CAG-CreER Rev- } \\
\text { erb } \alpha^{f / f l} \text { Rev-erb } \beta^{f l f l}\end{array}$ & ND & ND & Reduced & Yes & Yes $^{\circ}$ & ND & C57BL/6 \\
\hline Lamia et al. ${ }^{39}$ & Liver & Bmal1 & albumin-cre $B m a l 1^{f l f l}$ & Similar & ND & Normal & $\mathrm{No}^{p}$ & ND & No & $\begin{array}{l}\text { Mixed (C57BL/ } \\
6 \times 129)\end{array}$ \\
\hline Ma X et al. ${ }^{40}$ & Liver & Bmal1 & albumin-cre Bmal ${ }^{f l f f}$ & ND & ND & ND & $\mathrm{No}^{p}$ & ND & ND & $\begin{array}{l}\text { Mixed (C57BL } \\
6 \times 129)\end{array}$ \\
\hline Ma D et al. ${ }^{41}$ & Liver & Bmal1 & albumin-cre Bmal1 $1^{f l / f l}$ & ND & No & ND & ND & Yes & ND & C57BL6J \\
\hline Marcheva et al. ${ }^{5}$ & Pancreas & Bmal1 & Pdx-cre Bmal1 $1^{f l f l}$ & Similar & No & Normal & Yes & Yes & Yes & $\begin{array}{l}\text { Mixed (C57BL } \\
6 \times 129 \times I C R)\end{array}$ \\
\hline Lee et al. ${ }^{49}$ & Pancreas & Bmal1 & Rip-cre Bmal1 ${ }^{f l / f l}$ & Similar & No & Normal & Yes & ND & Yes & $\begin{array}{l}\text { Mixed (C57BL } \\
6 \mathrm{JxB6D2})\end{array}$ \\
\hline Paschos et al. ${ }^{27}$ & Adipose & Bmal1 & aP2-cre Bmal1 $1^{f l / f l}$ & Increase & Yes & Normal & Yes & Yes & No & C57BL6J \\
\hline Kettner et al. ${ }^{8}$ & Adipose & Bmal1 & aP2-cre Bmal1 $1^{f l f f}$ & ND & ND & ND & ND & ND & ND & C57BL/6J \\
\hline Westgate et al. ${ }^{55}$ & Vessel & Bmal1 & $\mathrm{Cre}^{T e k} \mathrm{Bmal} 1^{f \mid f l}$ & ND & ND & Reduced & ND & ND & ND & C57BL6J \\
\hline Dyar et al. ${ }^{59}$ & $\begin{array}{l}\text { Skeletal } \\
\text { muscle }\end{array}$ & Bmal1 & Mlc1f-cre Bmal $1^{f \mid f l}$ & Increase & ND & Increase & No & ND & ND & C57BL6 \\
\hline Dyar et al. ${ }^{59}$ & $\begin{array}{l}\text { Skeletal } \\
\text { muscle }\end{array}$ & Bmal1 & $\begin{array}{l}\text { HSA-MerCreMer } \\
\text { Bmal1 }\end{array}$ & Similar & ND & Normal & No & ND & ND & $\begin{array}{l}\text { Mixed (C57BL } \\
6 \times \mathrm{xC} 3 \mathrm{H})\end{array}$ \\
\hline Schroder et al. ${ }^{60}$ & $\begin{array}{l}\text { Skeletal } \\
\text { muscle }\end{array}$ & Bmal1 & $\begin{array}{l}\text { HSA-MerCreMer } \\
\text { Bmal1 }{ }^{f l f f}\end{array}$ & ND & No & Normal & ND & ND & ND & $\begin{array}{l}\text { Mixed (C57BL } \\
6 \times \mathrm{XC} 3 \mathrm{H})\end{array}$ \\
\hline
\end{tabular}

Abbreviations: DKO, double knockout; KO, knockout; ND, not described; WT, wild type.

All components compared under chow diet at normal physiological condition and response on stress varies between genotypes.

${ }^{a}$ Clock mutant mice have reduced body weight when fed a high-fat diet.

${ }^{b}$ Clock mutant mice have reduced insulin level when fed a high-fat diet.

${ }^{\mathrm{C}}$ Male Bmal1-null mice become mildly lean, but this is not significant in female mice.

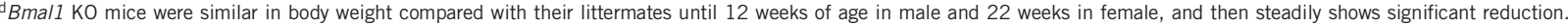

${ }^{\mathrm{e}} \mathrm{Bmal1} \mathrm{KO}$ group are significantly heavier initially at 3-5 weeks of age, but lose weight from 6 weeks of age, and this becomes significant from 10 weeks of age.

${ }^{\dagger}$ Bmall KO group have low plasma lipid level.

gPer2 KO group become hyperphagic under a high-fat diet.

${ }^{h}$ Circulating insulin is increased and glucose is reduced in the Per2 KO group.

iPer2 KO group have reduced glucose level.

${ }^{\mathrm{j} C} \mathrm{Cr} 1 \mathrm{KO}$ group have significant lower body weight when fed a high-fat diet.

${ }^{k}$ Cry1/Cry2 DKO mice gain weight when fed a high-fat diet. Under a high-fat diet, they eat less compared with WT mice.

ICry1/Cry2 DKO mice show a trend toward reduced activity in the dark phase both in a chow and high-fat diet, but activity looks increased in the light phase compared with WT mice.

${ }^{\mathrm{m} C r y 1 / C r y 2 ~ D K O ~ m i c e ~ h a v e ~ h i g h ~ i n s u l i n ~ l e v e l ~ w i t h ~ s y s t e m i c ~ g l u c o s e ~ i n t o l e r a n c e ~ c o m p a r e d ~ w i t h ~ W T ~ m i c e ~ w h e n ~ f e d ~ a ~ h i g h-f a t ~ d i e t . ~}$

${ }^{n}$ Rev-erb $\alpha$ KO group gain weight when fed a high-fat diet.

-Triglyceride is increased but free fatty acid is reduced in the KO group.

PLiver-specific Bmal1 KO group have reduced glucose level. 
animals, partly due to inhibition of the recruitment of Clock-Bmall to chromatin and activation of PPAR $\gamma \cdot{ }^{65}$ Several lines of evidence indicate that peripheral clock genes and clock-regulated genes in key metabolic organs such as the adipose tissue, liver and pancreas are critical regulators of systemic metabolic homeostasis. WT mice with dietary obesity and diabetes show blunting of the rhythmic oscillation of clock gene transcription in visceral fat and also partly in the liver but not in the skeletal muscle or blood vessels. In addition, mice with dietary obesity on a C57BL/6J background show abnormal Bmall and Per2 expression in adipose tissue along with a smaller alteration in the aorta, but show no changes in the liver or skeletal muscle. However, expression of clock-regulated genes such as Pepck (but not Rev-erba, $D b p$ and $P$ par- $\alpha$ ) was altered in the liver, whereas expression of Pepck, Rev-erba, Dbp and Ppar- $\alpha$ was altered in visceral fat. ${ }^{32}$ Nutritional challenge, rather than the development of obesity, was reported to cause reversible reprogramming of the hepatic clock. ${ }^{65}$ Changes of the cellular energy status would be involved in such alterations, but the exact mechanisms that link a high calorie intake to modification of the circadian clock are yet to be defined.

\section{CLOCK GENE POLYMORPHISM AND HUMAN METABOLIC DISORDERS}

Polymorphism of the CLOCK gene was reported to have a role in the development of diabetes in humans, which is associated with a low or high prevalence of metabolic syndrome according to the haplotype. ${ }^{66,67}$ Two BMAL1 haplotypes are also linked with susceptibility to diabetes. Although CRY1 polymorphism does not show a significant link with diabetes, this polymorphism increases the risk of systemic insulin resistance and diabetes when combined with high carbohydrate intake. ${ }^{68}$ Recent study reported that CRY1 and CRY2 variants show nominal association with the metabolic syndrome components. ${ }^{69}$ Accumulating evidence also suggests that diurnal changes of blood pressure are regulated by the biological clock. Genetic variants in circadian genes are reported to associate with hypertensive non-dippers, ${ }^{70}$ whereas melatonin secretion is significantly and inversely associated with nighttime blood pressure in a general elderly population without antihypertensive drug treatment. ${ }^{71}$ These results indicate that the clock genes are direct and indirect regulators of metabolic health in humans.

\section{SLEEP DISORDERS, CIRCADIAN RHYTHM AND METABOLIC SYNDROME}

It is well accepted that diurnal variation of physiological rhythms is important for health and disruption of the regular circadian rhythm by working night shifts or continuously rotating shifts increases the risk of developing obesity and diabetes. ${ }^{72}$ Several studies have indicated that there is a link between sleep disturbance, impaired circadian rhythms and metabolic disorders. Circadian misalignment induces postprandial glucose responses in the prediabetic range and promotes systemic insulin resistance with an increase of high sensitivity C-reactive protein and a low leptin level. ${ }^{73,74}$ Exposure to dim light at night disrupts both central and peripheral circadian rhythms, promoting weight gain and inflammation. ${ }^{75,76}$ The duration of sleep is also linked to metabolic homeostasis and the risk of diabetes. Inadequate sleep is a well-known risk factor for obesity and it was recently shown that long-term changes of sleep duration can also influence the risk of developing type 2 diabetes. ${ }^{77,78}$ In humans, insufficient sleep has been reported to influence the transcriptome, disrupt its circadian regulation and intensify the effects of acute total sleep deprivation. ${ }^{79}$ Obstructive sleep apnea develops with obesity, causing fragmentation of sleep and systemic hypoxia, and is well known to have a role in the progression of obesity and systemic insulin resistance. ${ }^{80}$ Obstructive sleep apnea promotes the development of obesity and insulin resistance in both adults and children. ${ }^{81}$ However, the circadian pattern of various hormones (such as adiponectin, leptin, ghrelin and resistin) shows no difference between persons with or without obstructive sleep apnea; thus, further studies are needed to assess the link between obstructive sleep apnea, circadian rhythm and metabolic disorders. Intake of food at specific times has been shown to have a profound influence on physiology. Restricted nighttime feeding with regular chow remarkably reduced the triglyceride level in WT mice, even though total daily caloric intake was unaffected. ${ }^{82}$ It was also reported that a time-restricted high-fat diet with equivalent calorie intake compared with ad libitum access had a protective effect against obesity, hyperinsulinemia, hepatic steatosis and inflammation. ${ }^{83}$ Furthermore, it was reported that restriction of the eating time per se, rather than the specific timing of restriction, is beneficial for suppressing metabolic dysfunction. ${ }^{84}$

Taken together, these studies indicate that circadian dyssynchrony promotes misalignment among the functions of various organs and has a pathological role in the development of systemic metabolic dysfunction. Considering that metabolic dysfunction itself promotes circadian dyssynchrony, a vicious cycle exists between obesity and clock dysfunction.

\section{CONCLUSIONS}

There is increasing evidence of a tight connection between metabolism and circadian rhythms, and it has been shown that metabolic stress promotes disturbance of clock-related genes in several key organs (Figure 1). Studies based on whole-body or tissue-specific depletion of clock genes have demonstrated the causal role of clock-related molecules in the maintenance of both organ and systemic metabolism. Phenotypic changes have shown some inconsistencies among the studies performed to date due to differences of animal background, study design or observation period (Table 1). ${ }^{4-8,11-16,20,27,35,39-41,49,55,59,60,85-90}$ Findings have been obtained that suggest the existence of a negative feedback loop between metabolic stress and clock dysfunction. Synchronization of behavior with metabolism by the body clock is crucial for maintenance of systemic metabolic homeostasis, but is often disrupted in modern society. Re-synchronization of circadian rhythms may be essential to combat obesity and diabetes.

\section{CONFLICT OF INTEREST}

The authors declare no conflict of interest.

\section{ACKNOWLEDGEMENTS}

This work was supported by a Grant-in-Aid for Scientific Research, a Grant-in-Aid for Scientific Research on Innovative Areas (Stem Cell Aging and Disease) and a Grant-in-Aid for Exploratory Research from the Ministry of Education, Culture, Sports, Science and Technology (MEXT) of Japan; grants from the Ono Medical Research Foundation, the Japan Diabetes Foundation, the Takeda Science Foundation and the Takeda Medical Research Foundation (to TM); by a Grant-in-Aid for Scientific Research from MEXT and grants from the Uehara Memorial Foundation, Takeda Science Foundation, Kowa Life Science Foundation, Manpei Suzuki Diabetes Foundation, Kanae Foundation, Japan Heart Foundation Research Grant, The Senri Life Science Foundation, SENSHIN Medical Research Foundation, ONO Medical Research Foundation, Tsukada Grant for Niigata University Medical Research, The Nakajima Foundation, SUZUKEN memorial foundation, HOKUTO Corporation, Mochida Memorial Foundation for Medical \& Pharmaceutical Research and Banyu Foundation, Grant for Basic Science Research Projects from the Sumitomo Foundation (to IS); by a Grant-in-Aid for Young Scientists from 
MEXT, a Japan Heart Foundation Dr Hiroshi Irisawa and Dr Aya Irisawa Memorial Research Grant, Senshin Medical Research Foundation grant, grants from the Uehara Memorial Foundation, SUZUKEN memorial foundation and Takeda Science Foundation and ONO Medical Research Foundation (to YY); and by a grant from Bourbon (to TM, IS and YY).

1 Damiola F, Le Minh N, Preitner N, Kornmann B, Fleury-Olela F, Schibler U. Restricted feeding uncouples circadian oscillators in peripheral tissues from the central pacemaker in the suprachiasmatic nucleus. Genes Dev 2000; 14: 2950-2961.

2 Bailey SM, Udoh US, Young ME. Circadian regulation of metabolism. J Endocrinol 2014; 222: R75-R96.

3 Vitaterna MH, King DP, Chang AM, Kornhauser JM, Lowrey PL, McDonald JD, Dove WF, Pinto LH, Turek FW, Takahashi JS. Mutagenesis and mapping of a mouse gene, Clock, essential for circadian behavior. Science 1994; 264: 719-725.

4 Turek FW, Joshu C, Kohsaka A, Lin E, Ivanova G, McDearmon E, Laposky A, Losee-Olson S, Easton A, Jensen DR, Eckel RH, Takahashi JS, Bass J. Obesity and metabolic syndrome in circadian Clock mutant mice. Science 2005; 308: 1043-1045.

5 Marcheva B, Ramsey KM, Buhr ED, Kobayashi Y, Su H, Ko CH, Ivanova G, Omura C, Mo S, Vitaterna MH, Lopez JP, Philipson LH, Bradfield CA, Crosby SD, JeBailey L, Wang X, Takahashi JS, Bass J. Disruption of the clock components CLOCK and BMAL1 leads to hypoinsulinaemia and diabetes. Nature 2010; 466: 627-631.

6 Shostak A, Meyer-Kovac J, Oster H. Circadian regulation of lipid mobilization in white adipose tissues. Diabetes 2013; 62: 2195-2203.

7 Kennaway DJ, Varcoe TJ, Voultsios A, Boden MJ. Global loss of bmal1 expression alters adipose tissue hormones, gene expression and glucose metabolism. PLOS ONE 2013; 8: e65255.

8 Kettner NM, Mayo SA, Hua J, Lee C, Moore DD, Fu L. Circadian dysfunction induces leptin resistance in mice. Cell Metab 2015; 22: 448-459.

9 Lee J, Kim MS, Li R, Liu VY, Fu L, Moore DD, Ma K, Yechoor VK. Loss of Bmal1 leads to uncoupling and impaired glucose-stimulated insulin secretion in beta-cells. Islets 2011; 3: 381-388.

10 Peek CB, Affinati AH, Ramsey KM, Kuo HY, Yu W, Sena LA, Ilkayeva O, Marcheva B, Kobayashi Y, Omura C, Levine DC, Bacsik DJ, Gius D, Newgard CB, Goetzman E, Chandel NS, Denu JM, Mrksich M, Bass J. Circadian clock NAD+ cycle drives mitochondrial oxidative metabolism in mice. Science 2013; 342: 1243417.

11 Grimaldi B, Bellet MM, Katada S, Astarita G, Hirayama J, Amin RH, Granneman JG, Piomelli D, Leff T, Sassone-Corsi P. PER2 controls lipid metabolism by direct regulation of PPARgamma. Cell Metab 2010; 12: 509-520.

12 Yang S, Liu A, Weidenhammer A, Cooksey RC, McClain D, Kim MK, Aguilera G, Abel ED, Chung JH. The role of mPer2 clock gene in glucocorticoid and feeding rhythms. Endocrinology 2009; 150: 2153-2160.

13 Zhao Y, Zhang Y, Zhou M, Wang S, Hua Z, Zhang J. Loss of mPer2 increases plasma insulin levels by enhanced glucose-stimulated insulin secretion and impaired insulin clearance in mice. FEBS Lett 2012; 586: 1306-1311.

14 Griebel G, Ravinet-Trillou C, Beeske S, Avenet P, Pichat P. Mice deficient in cryptochrome 1 (cryl $(-(-))$ exhibit resistance to obesity induced by a high-fat diet. Front Endocrinol (Lausanne) 2014; 5: 49

15 Lamia KA, Papp SJ, Yu RT, Barish GD, Uhlenhaut NH, Jonker JW, Downes M, Evans RM. Cryptochromes mediate rhythmic repression of the glucocorticoid receptor. Nature 2011; 480: 552-556.

16 Delezie J, Dumont S, Dardente H, Oudart H, Grechez-Cassiau A, Klosen P, Teboul M, Delaunay $F$, Pevet $P$, Challet $E$. The nuclear receptor REV-ERBalpha is required for the daily balance of carbohydrate and lipid metabolism. FASEB J 2012; 26: 3321-3335.

17 Bugge A, Feng D, Everett LJ, Briggs ER, Mullican SE, Wang F, Jager J, Lazar MA. Rev-erbalpha and Rev-erbbeta coordinately protect the circadian clock and normal metabolic function. Genes Dev 2012; 26: 657-667.

18 Cho H, Zhao X, Hatori M, Yu RT, Barish GD, Lam MT, Chong LW, DiTacchio L, Atkins AR, Glass CK, Liddle C, Auwerx J, Downes M, Panda S, Evans RM. Regulation of circadian behaviour and metabolism by REV-ERB-alpha and REV-ERB-beta. Nature 2012; 485: 123-127.

19 Solt LA, Wang Y, Banerjee S, Hughes T, Kojetin DJ, Lundasen T, Shin Y, Liu J, Cameron MD, Noel R, Yoo SH, Takahashi JS, Butler AA, Kamenecka TM, Burris TP. Regulation of circadian behaviour and metabolism by synthetic REV-ERB agonists. Nature 2012; 485: 62-68.

20 Woldt E, Sebti Y, Solt LA, Duhem C, Lancel S, Eeckhoute J, Hesselink MK, Paquet C, Delhaye S, Shin Y, Kamenecka TM, Schaart G, Lefebvre P, Neviere R, Burris TP, Schrauwen P, Staels B, Duez H. Rev-erb-alpha modulates skeletal muscle oxidative capacity by regulating mitochondrial biogenesis and autophagy. Nat Med 2013; 19: 1039-1046.

21 Zhang Y, Fang B, Emmett MJ, Damle M, Sun Z, Feng D, Armour SM, Remsberg JR, Jager J, Soccio RE, Steger DJ, Lazar MA. GENE REGULATION. Discrete functions of nuclear receptor Rev-erbalpha couple metabolism to the clock. Science 2015; 348: 1488-1492.

22 Kohsaka A, Laposky AD, Ramsey KM, Estrada C, Joshu C, Kobayashi Y, Turek FW, Bass J. High-fat diet disrupts behavioral and molecular circadian rhythms in mice. Cell Metab 2007; 6: 414-421.

23 Yamamoto $\mathrm{H}$, Nagai K, Nakagawa $\mathrm{H}$. Role of $\mathrm{SCN}$ in daily rhythms of plasma glucose, FFA, insulin and glucagon. Chronobiol Int 1987; 4: 483-491.
24 Van den Pol AN, Powley T. A fine-grained anatomical analysis of the role of the rat suprachiasmatic nucleus in circadian rhythms of feeding and drinking. Brain Res 1979; 160: 307-326.

25 Coomans CP, van den Berg SA, Lucassen EA, Houben T, Pronk AC, van der Spek RD, Kalsbeek A, Biermasz NR, Willems van Dijk K, Romijn JA, Meijer JH. The suprachiasmatic nucleus controls circadian energy metabolism and hepatic insulin sensitivity. Diabetes 2013; 62: 1102-1108.

26 Mendoza J, Pevet P, Challet E. High-fat feeding alters the clock synchronization to light. J Physiol 2008; 586: 5901-5910.

27 Paschos GK, Ibrahim S, Song WL, Kunieda T, Grant G, Reyes TM, Bradfield CA, Vaughan $\mathrm{CH}$, Eiden M, Masoodi M, Griffin JL, Wang F, Lawson JA, Fitzgerald GA. Obesity in mice with adipocyte-specific deletion of clock component Arntl. Nat Med 2012; 18: 1768-1777.

28 Zvonic S, Ptitsyn AA, Conrad SA, Scott LK, Floyd ZE, Kilroy G, Wu X, Goh BC, Mynatt RL, Gimble JM. Characterization of peripheral circadian clocks in adipose tissues. Diabetes 2006; 55: 962-970.

29 Gomez-Abellan P, Hernandez-Morante JJ, Lujan JA, Madrid JA, Garaulet M. Clock genes are implicated in the human metabolic syndrome. Int J Obes (Lond) 2008; 32: 121-128.

30 Ando $\mathrm{H}$, Yanagihara H, Hayashi $\mathrm{Y}$, Obi Y, Tsuruoka S, Takamura T, Kaneko S, Fujimura A. Rhythmic messenger ribonucleic acid expression of clock genes and adipocytokines in mouse visceral adipose tissue. Endocrinology 2005; 146: 5631-5636.

31 Otway DT, Mantele S, Bretschneider S, Wright J, Trayhurn P, Skene DJ, Robertson MD, Johnston JD. Rhythmic diurnal gene expression in human adipose tissue from individuals who are lean, overweight, and type 2 diabetic. Diabetes 2011; 60: 1577-1581.

32 Prasai MJ, Mughal RS, Wheatcroft SB, Kearney MT, Grant PJ, Scott EM. Diurnal variation in vascular and metabolic function in diet-induced obesity: divergence of insulin resistance and loss of clock rhythm. Diabetes 2013; 62: 1981-1989.

33 Shimizu I, Aprahamian T, Kikuchi R, Shimizu A, Papanicolaou KN, MacLauchlan S, Maruyama S, Walsh K. Vascular rarefaction mediates whitening of brown fat in obesity. J Clin Invest 2014; 124: 2099-2112.

34 Bartelt A, Bruns OT, Reimer R, Hohenberg H, Ittrich H, Peldschus K, Kaul MG, Tromsdorf UI, Weller H, Waurisch C, Eychmuller A, Gordts PL, Rinninger F, Bruegelmann K, Freund B, Nielsen P, Merkel M, Heeren J. Brown adipose tissue activity controls triglyceride clearance. Nat Med 2011; 17: 200-205.

35 Nam D, Guo B, Chatterjee S, Chen MH, Nelson D, Yechoor VK, Ma K. The adipocyte clock controls brown adipogenesis through the TGF-beta and BMP signaling pathways. J Cell Sci 2015; 128: 1835-1847.

36 Xu H, Li H, Woo SL, Kim SM, Shende VR, Neuendorff N, Guo X, Guo T, Qi T, Pei Y, Zhao Y, Hu X, Zhao J, Chen L, Chen L, Ji JY, Alaniz RC, Earnest DJ, Wu C. Myeloid cellspecific disruption of Period 1 and Period2 exacerbates diet-induced inflammation and insulin resistance. J Biol Chem 2014; 289: 16374-16388.

37 Sato S, Sakurai T, Ogasawara J, Takahashi M, Izawa T, Imaizumi K, Taniguchi N, Ohno H, Kizaki T. A circadian clock gene, Rev-erbalpha, modulates the inflammatory function of macrophages through the negative regulation of $\mathrm{Ccl} 2$ expression. J Immunol 2014; 192: 407-417.

38 Targher G, Day CP, Bonora E. Risk of cardiovascular disease in patients with nonalcoholic fatty liver disease. N Engl J Med 2010; 363: 1341-1350.

39 Lamia KA, Storch KF, Weitz CJ. Physiological significance of a peripheral tissue circadian clock. Proc Natl Acad Sci USA 2008; 105: 15172-15177.

$40 \mathrm{Ma}$ X, Zhou Z, Chen Y, Wu Y, Liu Y. RBP4 functions as a hepatokine in the regulation of glucose metabolism by the circadian clock in mice. Diabetologia 2015; 59: 354-362.

41 Ma D, Liu T, Chang L, Rui C, Xiao Y, Li S, Hogenesch JB, Chen YE, Lin JD. The liver clock controls cholesterol homeostasis through Trib1-mediated regulation of PCSK9/ LDLR. J Biol Chem 2015; 290: 31003-31012.

42 Zhang EE, Liu Y, Dentin R, Pongsawakul PY, Liu AC, Hirota T, Nusinow DA, Sun X, Landais S, Kodama Y, Brenner DA, Montminy M, Kay SA. Cryptochrome mediates circadian regulation of CAMP signaling and hepatic gluconeogenesis. Nat Med 2010; 16: $1152-1156$.

43 Rakshit K, Qian J, Colwell CS, Matveyenko AV. The islet circadian clock: entrainment mechanisms, function and role in glucose homeostasis. Diabetes Obes Metab 2015; 17 (Suppl 1): 115-122.

44 Vieira E, Marroqui L, Batista TM, Caballero-Garrido E, Carneiro EM, Boschero AC, Nadal A, Quesada I. The clock gene Rev-erbalpha regulates pancreatic beta-cell function: modulation by leptin and high-fat diet. Endocrinology 2012; 153: 592-601.

45 Muhlbauer E, Wolgast S, Finckh U, Peschke D, Peschke E. Indication of circadian oscillations in the rat pancreas. FEBS Lett 2004; 564: 91-96.

46 Stamenkovic JA, Olsson AH, Nagorny CL, Malmgren S, Dekker-Nitert M, Ling C, Mulder H. Regulation of core clock genes in human islets. Metabolism 2012; 61: 978-985.

47 Qian J, Yeh B, Rakshit K, Colwell CS, Matveyenko AV. Circadian disruption and diet-induced obesity synergize to promote development of beta cell failure and diabetes in male rats. Endocrinology 2015; 156: 4426-4436.

48 Perelis M, Marcheva B, Ramsey KM, Schipma MJ, Hutchison AL, Taguchi A, Peek CB, Hong $\mathrm{H}$, Huang W, Omura C, Allred AL, Bradfield CA, Dinner AR, Barish GD, Bass J. Pancreatic beta cell enhancers regulate rhythmic transcription of genes controlling insulin secretion. Science 2015; 350: aac4250.

49 Lee J, Moulik M, Fang Z, Saha P, Zou F, Xu Y, Nelson DL, Ma K, Moore DD, Yechoor VK. Bmal1 and beta-cell clock are required for adaptation to circadian disruption, and their loss of function leads to oxidative stress-induced beta-cell failure in mice. Mol Cell Biol 2013; 33: 2327-2338. 
50 Oishi K, Ohkura N, Wakabayashi M, Shirai H, Sato K, Matsuda J, Atsumi G, Ishida N. CLOCK is involved in obesity-induced disordered fibrinolysis in ob/ob mice by regulating PAl-1 gene expression. J Thromb Haemost 2006; 4: 1774-1780.

51 Takeda N, Maemura K, Horie S, Oishi K, Imai Y, Harada T, Saito T, Shiga T, Amiya E, Manabe I, Ishida N, Nagai R. Thrombomodulin is a clock-controlled gene in vascular endothelial cells. J Biol Chem 2007; 282: 32561-32567.

52 Anea CB, Zhang M, Stepp DW, Simkins GB, Reed G, Fulton DJ, Rudic RD. Vascular disease in mice with a dysfunctional circadian clock. Circulation 2009; 119: 1510-1517.

53 Viswambharan H, Carvas JM, Antic V, Marecic A, Jud C, Zaugg CE, Ming XF, Montani JP, Albrecht U, Yang Z. Mutation of the circadian clock gene Per2 alters vascular endothelial function. Circulation 2007; 115: 2188-2195.

54 Kunieda T, Minamino T, Miura K, Katsuno T, Tateno K, Miyauchi H, Kaneko S, Bradfield CA, FitzGerald GA, Komuro I. Reduced nitric oxide causes age-associated impairment of circadian rhythmicity. Circ Res 2008; 102: 607-614.

55 Westgate EJ, Cheng Y, Reilly DF, Price TS, Walisser JA, Bradfield CA, FitzGerald GA. Genetic components of the circadian clock regulate thrombogenesis in vivo. Circulation 2008; 117: 2087-2095.

56 Yokoyama M, Okada S, Nakagomi A, Moriya J, Shimizu I, Nojima A, Yoshida Y, Ichimiya $\mathrm{H}$, Kamimura N, Kobayashi $\mathrm{Y}$, Ohta S, Fruttiger M, Lozano G, Minamino $T$. Inhibition of endothelial p53 improves metabolic abnormalities related to dietary obesity. Cell Rep 2014; 7: 1691-1703.

57 Harrison BC, Leinwand LA. Fighting fat with muscle: bulking up to slim down. Cell Metab 2008; 7: 97-98.

58 Izumiya Y, Hopkins T, Morris C, Sato K, Zeng L, Viereck J, Hamilton JA, Ouchi N, LeBrasseur NK, Walsh K. Fast/Glycolytic muscle fiber growth reduces fat mass and improves metabolic parameters in obese mice. Cell Metab 2008; 7: 159-172.

59 Dyar KA, Ciciliot S, Wright LE, Bienso RS, Tagliazucchi GM, Patel VR, Forcato M, Paz MI, Gudiksen A, Solagna F, Albiero M, Moretti I, Eckel-Mahan KL, Baldi P, Sassone-Corsi P, Rizzuto R, Bicciato S, Pilegaard H, Blaauw B, Schiaffino S. Muscle insulin sensitivity and glucose metabolism are controlled by the intrinsic muscle clock. Mol Metab 2014; 3: 29-41.

60 Schroder EA, Harfmann BD, Zhang X, Srikuea R, England JH, Hodge BA, Wen $Y$ Riley LA, Yu Q, Christie A, Smith JD, Seward T, Horrell EM, Mula J, Peterson CA, Butterfield TA, Esser KA. Intrinsic muscle clock is necessary for musculoskeletal health. J Physiol 2015; 593: 5387-5404.

61 Tremaroli V, Backhed F. Functional interactions between the gut microbiota and host metabolism. Nature 2012; 489: 242-249.

62 Thaiss CA, Zeevi D, Levy M, Zilberman-Schapira G, Suez J, Tengeler AC, Abramson L, Katz MN, Korem T, Zmora N, Kuperman Y, Biton I, Gilad S, Harmelin A, Shapiro H, Halpern Z, Segal E, Elinav E. Transkingdom control of microbiota diurnal oscillations promotes metabolic homeostasis. Cell 2014; 159: 514-529.

63 Liang X, Bushman FD, FitzGerald GA. Rhythmicity of the intestinal microbiota is regulated by gender and the host circadian clock. Proc Natl Acad Sci USA 2015; 112: 10479-10484.

64 Kudo T, Akiyama M, Kuriyama K, Sudo M, Moriya T, Shibata S. Night-time restricted feeding normalises clock genes and Pai-1 gene expression in the $\mathrm{db} / \mathrm{db}$ mouse liver Diabetologia 2004; 47: 1425-1436.

65 Eckel-Mahan KL, Patel VR, de Mateo S, Orozco-Solis R, Ceglia NJ, Sahar S, Dilag-Penilla SA, Dyar KA, Baldi P, Sassone-Corsi P. Reprogramming of the circadian clock by nutritional challenge. Cell 2013; 155: 1464-1478.

66 Scott EM, Carter AM, Grant PJ. Association between polymorphisms in the Clock gene, obesity and the metabolic syndrome in man. Int J Obes (Lond) 2008; 32: 658-662.

67 Valladares M, Obregon AM, Chaput JP. Association between genetic variants of the clock gene and obesity and sleep duration. J Physiol Biochem 2015; 71: 855-860.

68 Dashti HS, Smith CE, Lee YC, Parnell LD, Lai CQ, Arnett DK, Ordovas JM, Garaulet M. CRY1 circadian gene variant interacts with carbohydrate intake for insulin resistance in two independent populations: Mediterranean and North American. Chronobiol Int 2014; 31: 660-667.

69 Kovanen L, Donner K, Kaunisto M, Partonen T. CRY1, CRY2 and PRKCDBP genetic variants in metabolic syndrome. Hypertens Res 2015; 38: 186-192.

70 Leu HB, Chung CM, Lin SJ, Chiang KM, Yang HC, Ho HY, Ting CT, Lin TH, Sheu SH, Tsai WC, Chen JH, Yin WH, Chiu TY, Chen Cl, Fann CS, Chen YT, Pan WH, Chen JW. Association of circadian genes with diurnal blood pressure changes and non-dipper essential hypertension: a genetic association with young-onset hypertension. Hypertens Res 2015; 38: 155-162.

71 Obayashi K, Saeki K, Tone N, Kurumatani N. Relationship between melatonin secretion and nighttime blood pressure in elderly individuals with and without antihypertensive treatment: a cross-sectional study of the HEIJO-KYO cohort. Hypertens Res 2014; 37: 908-913.

72 Karlsson BH, Knutsson AK, Lindahl BO, Alfredsson LS. Metabolic disturbances in male workers with rotating three-shift work. Results of the WOLF study. Int Arch Occup Environ Health 2003; 76: 424-430.

73 Scheer FA, Hilton MF, Mantzoros CS, Shea SA. Adverse metabolic and cardiovascular consequences of circadian misalignment. Proc Natl Acad Sci USA 2009; 106: 4453-4458.

74 Leproult R, Holmback U, Van Cauter E. Circadian misalignment augments markers of insulin resistance and inflammation, independently of sleep loss. Diabetes 2014; 63 1860-1869.

75 Fonken LK, Lieberman RA, Weil ZM, Nelson RJ. Dim light at night exaggerates weight gain and inflammation associated with a high-fat diet in male mice. Endocrinology 2013; 154: 3817-3825

76 Fonken LK, Workman JL, Walton JC, Weil ZM, Morris JS, Haim A, Nelson RJ. Light at night increases body mass by shifting the time of food intake. Proc Natl Acad Sci USA 2010; 107: 18664-18669.

77 Gangwisch JE, Malaspina D, Boden-Albala B, Heymsfield SB. Inadequate sleep as a risk factor for obesity: analyses of the NHANES I. Sleep 2005; 28: 1289-1296.

78 Cespedes EM, Bhupathiraju SN, Li Y, Rosner B, Redline S, Hu FB. Long-term changes in sleep duration, energy balance and risk of type 2 diabetes. Diabetologia 2015; 59: 101-109.

79 Moller-Levet CS, Archer SN, Bucca G, Laing EE, Slak A, Kabiljo R, Lo JC, Santhi N, von Schantz M, Smith CP, Dijk DJ. Effects of insufficient sleep on circadian rhythmicity and expression amplitude of the human blood transcriptome. Proc Natl Acad Sci USA 2013; 110: E1132-E1141.

80 Reutrakul S, Van Cauter E. Interactions between sleep, circadian function, and glucose metabolism: implications for risk and severity of diabetes. Ann N Y Acad Sci 2014; 1311: 151-173.

81 Koren D, O'Sullivan KL, Mokhlesi B. Metabolic and glycemic sequelae of sleep disturbances in children and adults. Curr Diab Rep 2015; 15: 562.

82 Adamovich Y, Aviram R, Asher G. The emerging roles of lipids in circadian control. Biochim Biophys Acta 2015; 1851: 1017-1025.

83 Hatori M, Vollmers C, Zarrinpar A, DiTacchio L, Bushong EA, Gill S, Leblanc M, Chaix A, Joens M, Fitzpatrick JA, Ellisman MH, Panda S. Time-restricted feeding without reducing caloric intake prevents metabolic diseases in mice fed a high-fat diet. Cell Metab 2012; 15: 848-860.

84 Asher G, Sassone-Corsi P. Time for food: the intimate interplay between nutrition, metabolism, and the circadian clock. Cell 2015; 161: 84-92.

85 Rudic RD, McNamara P, Curtis AM, Boston RC, Panda S, Hogenesch JB, Fitzgerald GA. BMAL1 and CLOCK, two essential components of the circadian clock, are involved in glucose homeostasis. PLoS Biol 2004; 2: e377.

86 Oishi K. Atsumi G, Sugiyama S, Kodomari I, Kasamatsu M, Machida K, Ishida N. Disrupted fat absorption attenuates obesity induced by a high-fat diet in Clock mutant mice. FEBS Lett 2006; 580: 127-130.

87 Doi R, Oishi K, Ishida N. CLOCK regulates circadian rhythms of hepatic glycogen synthesis through transcriptional activation of Gys2. J Biol Chem 2010; 285: 22114-22121.

88 Chappuis S, Ripperger JA, Schnell A, Rando G, Jud C, Wahli W, Albrecht U. Role of the circadian clock gene Per2 in adaptation to cold temperature. Mol Metab 2013; 2 184-193.

89 Zani F, Breasson L, Becattini B, Vukolic A, Montani JP, Albrecht U, Provenzani A, Ripperger JA, Solinas G. PER2 promotes glucose storage to liver glycogen during feeding and acute fasting by inducing Gys2 PTG and G L expression. Mol Metab 2013; 2: 292-305.

90 Barclay JL, Shostak A, Leliavski A, Tsang AH, Johren O, Muller-Fielitz H, Landgraf D, Naujokat N, van der Horst GT, Oster $\mathrm{H}$. High-fat diet-induced hyperinsulinemia and tissue-specific insulin resistance in Cry-deficient mice. Am J Physiol Endocrinol Metab 2013; 304: E1053-E1063. 